Jurnal Keperawatan Silampari

Volume 4, Nomor 1, Desember 2020

e-ISSN: 2581-1975

p-ISSN: 2597-7482

DOI: https://doi.org/10.31539/jks.v4i1.1545

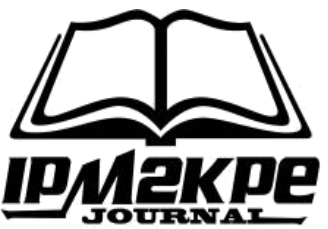

\title{
MENIUP SUPER BUBBLES DAN BALING-BALING BAMBOO PADA ANAK PENDERITA PNEUMONIA
}

\author{
Padila $^{1}$, Harsismanto $\mathrm{J}^{2}$, Lussyefrida Yanti ${ }^{3}$, Setiawati ${ }^{4}$, Juli Andri ${ }^{5}$ \\ Universitas Muhammadiyah Bengkulu ${ }^{1,2,3,5}$ \\ Sekolah Tinggi Ilmu Kesehatan Jenderal Achmad Yani Bandung ${ }^{4}$ \\ padila@umb.ac.id ${ }^{1}$
}

\begin{abstract}
ABSTRAK
Penelitian ini bertujuan untuk mengetahui pengaruh tiup super bubbles dan meniup baling-baling bamboo terhadap frekuensi pernafasan anak penderita pneumonia. Desain penelitian pre-test dan post-test two group. Hasil analisis univariat sebelum dilakukan terapi tiup super bubbles frekuensi pernafasan seluruh responden termasuk dalam kategori sedang yaitu 10 (100\%) responden, dan setelah dilakukan intervensi terjadi perubahan menjadi kategori ringan yaitu sebanyak 3 (30\%) responden. Sedangkan sebelum dilakukan terapi meniup baling-baling bamboo frekuensi pernafasan responden mayoritas termasuk dalam kategori sedang yaitu sebanyak $8(80 \%)$ responden, dan setelah dilakukan terapi frekuensi pernafasan responden seimbang antara kategori sedang dan ringan yaitu masing-masing sebanyak (50\%) responden. Hasil analisis bivariat terdapat pengaruh tiup super bubbles dan meniup baling-baling bamboo terhadap frekuensi pernafasan anak dengan masing-masing $\mathrm{p}$ value 0,000 , dan 0,006 . Simpulan, intervensi terapi tiup super bubbles dan meniup baling baling berpengaruh terhadap frekuensi pernafasan anak penderita pneumonia.
\end{abstract}

Kata Kunci: Baling-Baling Bamboo, Frekuensi Pernafasan, Tiup Super Bubbles

\begin{abstract}
This study aims to determine the effect of blowing superbubbles and blowing bamboo propellers on children's respiratory frequency with pneumonia. The study design was pretest and post-test two groups. The results of the univariate analysis before the blow therapy were carried out. Super bubbles, the respiratory frequency of all respondents was included in the moderate category, namely $10(100 \%)$ respondents. After the intervention, there was a change to the mild type, namely as many as 3 (30\%) respondents. Whereas before the therapy of blowing bamboo propellers, the respiratory frequency of the majority of respondents was included in the medium category, namely as many as 8 (80\%) of respondents, and after therapy, the respiration frequency was balanced between the moderate and light types, namely as many as 50\% of respondents respectively. The bivariate analysis results showed the effect of blowing superbubbles and blowing bamboo propellers on the respiratory frequency of the children with a p-value of 0.000, and 0.006, respectively. In conclusion, the intervention of blowing superbubbles and blowing propeller affects the respiratory frequency of children with pneumonia.
\end{abstract}

Keywords: Baling-Baling Bamboo, Respiratory Frequency, Blow Super Bubbles 


\section{PENDAHULUAN}

Pneumonia merupakan infeksi yang menyerang parenkim paru dan jaringan interstisial di alveolus yang disebabkan oleh bakteri, dengan tanda dan gejalanya seperti demam tinggi, batuk berdahak, frekuensi napas cepat > $50 \mathrm{x} / \mathrm{menit}$, sesak napas, sakit kepala, gelisah, nafsu makan berkurang (Ihsaniah, 2019).

Insiden pneumonia pada anak kurang dari lima tahun di Negara berkembang lebih tinggi bila dibandingkan dengan Negara maju, yaitu sebesar 10-20 kasus/100 anak dalam setahun sehingga menyebabkan lebih dari 5 juta kematian pertahun pada Balita. Menurut Riskesdas (2018) menunjukkan bahwa terjadi peningkatan prevalensi pneumonia dari 1,6\% pada tahun 2013 menjadi $2 \%$ pada tahun 2018 dari populasi balita yang ada diIndonesia pada tahun 2018. Selama beberapa tahun terakhir cakupan pneumonia tidak pernah mencapai target nasional. Capaian pada tahun 2015 hanya sebesar 14,64\% dari yang ditargetkan sebesar $20 \%$ pada seluruh kabupaten dan kota yang ada (Apriliza \& Zulaikha, 2018).

Pneumonia ditandai dengan distress pernapasan. Distress pernapasan merupakan kompensasi tubuh saat terjadinya gangguan oksigen, konsentrasi oksigen yang rendah menstimulus syaraf pusat untuk meningkatkan frekuensi nafas cepat. Bila upaya ini tidak terkompensasi, berdampak pada status gangguan oksigenasi dari ringan hingga berat serta menimbulkan kegawatan (Muliasari \& Indrawati, 2018).

Upaya yang telah dilakukan oleh pemerintah terhadap penyakit ISPA yaitu : Penemuan kasus pneumonia dilakukan secara aktif dan pasif, peningkatan mutu pelayanan melalui ketersediaan tenaga terlatih dan logistik, peningkatan peran serta masyarakat dalam rangka deteksi dini pneumonia balita dan pencarian pengobatan ke fasilitas pelayanan kesehatan, dan pelaksanaan autopsi verbal balita di masyarakat (Kemenkes RI, 2017; Padila et al., 2019).

Selain itu, usaha yang dapat dilakukan untuk memperbaiki frekuensi pernafasan pada anak dengan pneumonia adalah dengan cara farmakologi dan non farmakologi. Pengobatan farmakologis pada pneumonia biasanya dengan oksigenisasi dan melibatkan pengobatan beta 2 adrenergik, sedangkan pengobatan non farmakologis biasanya dengan menghindari faktor penyebab dan menciptakan lingkungan yang sehat. Beberapa hasil penelitian memperjelas bahwa latihan non farmakologis seperti pursed lips breathing, relaksasi pernafasan dalam, bermain meniup balon, dan meniup baling-baling bamboo mampu mempengaruhi pola pernapasan pasien dan meningkatkan status oksigenasi pada pasien pneumonia dan tuberculosis (Ihsaniah, 2019; Irfan et al., 2019).

Penelitian yang dilakukan oleh Wahidati et al, (2019) suatu penelitian quasi eksperimental dengan jumlah sampel 34 responden didapatkan hasil pursed lips breathing lebih efektif dengan rata-rata 1,23 dibandingkan dengan tripod position 0,29. Latiahan nafas dapat membantu meningkatkan masuknya oksigen ke alveoli sehingga meningkatkan saturasi oksigen.

Machsun et al., (2018) telah melakukan penelitian terkait perbandingan efektifitas tehnik relaksasi napas dalam dengan meniup baling-baling terhadap penurunan skala nyeri fungsi vena pada anak usia prasekolah.

Dari beberapa penelitian terdahulu tersebut yang telah dilakukan hanya memberikan satu intervensi saja pada pasien tuberculosis dan asma yang mengalami nyeri dada dan ansietas saja, namun dalam penelitian ini ingin melihat pengaruh tiup super bubbles dan meniup baling-baling bambu terhadap frekuensi pernafasan anak penderita pneumonia. 


\section{METODE PENELITIAN}

Penelitian yang dilakukan terhadap anak usia pra sekolah menggunakan rancangan quasy eksperimen dengan pre test and post test two grup design. Dimana penelitian dilakukan terhadap kedua kelompok eksperimen yaitu kelompok tiup super bubbles dan kelompok meniup baling-baling bambu. Pada penelitian ini menggunakan uji $t$-dependent dan $t$-independent. Uji $t$-dependent digunakan untuk melihat pengaruh terhadap kelompok yang datanya saling mempunyai ketergantungan saling berhubungan, sedangkan uji $t$ independent digunakan untuk mengetahui perbandingan efektivitas pada kedua kelompok yang berbeda.

Sampel dalam penelitian ini sebanyak 20 orang yang terbagi dalam dua kelompok dengan 10 orang pada kelompok tiup super bubbles dan 10 orang pada kelompok meniup baling-baling bamboo.

\section{HASILPENELITIAN}

Analisa Univariat

Tabel. 1

Rata-Rata Frekuensi Pernafasan pada Anak Penderita Pneumonia

Sebelum dan Setelah Melakukan Terapi Tiup Super Bubbles

\begin{tabular}{ccc}
\hline Super Bubbels & Frekuensi & Persentase \\
\hline Frekuensi Pernafasan Pre & & \\
Sedang & 10 & 100,0 \\
Ringan & 0 & 0,0 \\
\hline Total & 10 & 100,0 \\
\hline Frekuensi Pernafasan Post & & 70,0 \\
Sedang & 7 & 30,0 \\
Ringan & 3 & 100,0 \\
\hline Total & 10 &
\end{tabular}

Berdasarkan tabel 1 dapat diketahui sebelum dilakukan terapi tiup super bubbles frekuensi pernafasan seluruh responden termasuk dalam kategori sedang yaitu $10(100 \%)$ responden, dan setelah dilakukan tiup super bubbles frekuensi pernafasan responden terjadi perubahan menjadi kategori ringan yaitu sebanyak 3 (30\%) responden.

Tabel. 2

Rata-Rata Frekuensi Pernafasan pada Anak Penderita Pneumonia Sebelum dan Setelah Melakukan Terapi Meniup Baling-Baling Bamboo

\begin{tabular}{ccc}
\hline Meniup Baling-Baling Bamboo & Frekuensi & Persentase \\
\hline Frekuensi Pernafasan Pre & & \\
Sedang & 8 & 80,0 \\
Ringan & 2 & 20,0 \\
\hline Total & 10 & 100,0 \\
\hline Frekuensi Pernafasan Post & & \\
Sedang & 5 & 50,0 \\
Ringan & 5 & 50,0 \\
\hline Total & 10 & 100,0
\end{tabular}

Berdasarkan tabel 2 dapat diketahui sebelum dilakukan terapi meniup baling-baling bamboo frekuensi pernafasan responden mayoritas termasuk dalam kategori sedang yaitu sebanyak 8 (80\%) responden, dan setelah dilakukan terapi meniup baling-baling frekuensi 
pernafasan responden seimbang antara kategori sedang dan ringan yaitu masing-masing sebanyak $(50 \%)$ responden.

\section{Analisa Bivariat}

Tabel. 3

Pengaruh Frekuensi Pernafasan pada Anak Penderita Pneumonia Sebelum dan Setelah Dilakukan Terapi Tiup Super Bubbles

\begin{tabular}{ccccc}
\hline Variabel & $\mathrm{N}$ & Std. Deviation & Ratio Interval & P value \\
\hline $\begin{array}{c}\text { Frekuensi Pernafasan } \\
\text { Sebelum }\end{array}$ & 10 & 0,930 & & \\
$\begin{array}{c}\text { Frekuensi Pernafasan } \\
\text { Setelah }\end{array}$ & & 1,390 & $1.20651-2,64091$ & 0,000 \\
\hline
\end{tabular}

Berdasarkan tabel 3 didapatkan bahwa dari hasil uji statistic didapatkan nilai $p$ value 0,000, maka dapat disimpulkan bahwa ada pengaruh tiup super bubbles terhadap frekuensi pernafasan pada anak pada penderita pneumonia.

Tabel. 4

Pengaruh Frekuensi Pernafasan pada Anak Penderita Pneumonia Sebelum dan Setelah Dilakukan Terapi Meniup Baling-Baling Bambu

\begin{tabular}{ccccc}
\hline Variabel & N & Std. Deviation & Ratio Interval & Pvalue \\
\hline $\begin{array}{c}\text { Frekuensi } \\
\text { Pernafasan Sebelum }\end{array}$ & 10 & 24.3610 & & \\
\hline $\begin{array}{c}\text { Frekuensi } \\
\text { Pernafasan Setelah }\end{array}$ & & 23.3200 & $0,36201-1,34838$ & 0,006 \\
\hline
\end{tabular}

Berdasarkan tabel 4 didapatkan bahwa dari hasil uji statistic didapatkan nilai $p$ value 0,006, maka dapat disimpulkan bahwa ada pengaruh meniup baling-baling bambu terhadap frekuensi pernafasan pada anak pada penderita pneumonia.

\section{PEMBAHASAN}

\section{Analisa Univariat}

Berdasarkan tabel 1 dapat diketahui bahwa terjadi perubahan rata-rata terhadap frekuensi pernafasan sebelum dan melakukan terapi tiup super bubbles. Hal ni sesuai dengan penelitian yang dilakukan oleh Widiyatmoko \& Nur (2018) yang menyebutkan bahwa terjadi penurunan kecemasan anak yang diberikan terapi super bubbles dari ratarata 10,19 turun menjadi 4,90. Hal ini membuktikan bahwa terapi bermain super bubbles membantu mengurangi ketegangan dan kecemasan yang dialami oleh anak pra sekolah sehingga dapat memberikan distraksi dan relaksasi melalui permainan.

Berdasarkan tabel 2 dapat diketahui rata-rata frekuensi pernafasan sebelum dan setelah melakukan terapi meniup baling-baling bambu. Berdasarkan tabel 2 dapat diketahui bahwa terjadi perubahan rata-rata terhadap frekuensi pernafasan sebelum dan setelah melakukan terapi meniup baling-baling bambu yaitu sedang.

Hal ini didukung oleh penelitian Suwastika (2017) yang membandingkan tingkat kecemasan pada anak pra sekolah dengan hospitalisasi melalui terapi meniup balingbaling. Dari hasil penelitian tersebut diketahui bahwa dari 30 responden terjadi perubahan rata-rata frekuensi tingkat kecemasan yaitu diketahui bahwa sebelum perlakuan sebanyak 
$60 \%$ responden mengalami tingkat kecemasan sedang dan setelah perlakuan didapati hasil $80 \%$ responden tidak mengalami kecemasan.

\section{Analisa Bivariat}

Berdasarkan tabel 3 hasil penelitian dengan melakukan uji statistic t-dependent menunjukkan bahwa ada pengaruh tiup super bubbles terhadap frekuensi pernafasan pada anak pada penderita pneumonia. Hal ini menunjukkan bahwa tiup super bubbles memiliki peranan dalam penurunan frekuensi pernafasan, sehingga terjadi perubahan pada frekuensi pernapasan anak yang mengalami pneumonia. Pasien pneumonia mengalami penyempitan jalan nafas karena hiperaktivitas terhadap rangsangan tertentu, yang menyebabkan peradangan dan penyempitan yang bersifat sementara.

Usaha yang dapat dilakukan untuk memperbaiki frekuensi pernafasan pada anak dengan pneumonia adalah dengan cara farmakologi dan non farmakologi. Pengobatan farmakologis pada pneumonia biasanya dengan oksigenisasi dan melibatkan pengobatan beta 2 adrenergik, sedangkan pengobatan non farmakologis biasanya dengan menghindari faktor penyebab dan menciptakan lingkungan yang sehat. Beberapa hasil penelitian memperjelas bahwa latihan non farmakologis seperti pursed lips breathing, relaksasi pernafasan dalam, bermain meniup balon, dan meniup baling-baling bamboo mampu mempengaruhi pola pernapasan pasien dan meningkatkan status oksigenasi pada pasien pneumonia dan tuberculosis (Ihsaniah, 2019; Irfan et al., 2019).

Latihan pernafasan dapat dilakukan dalam beberapa posisi karena distribusi udara dan sirkulasi pulmonal beragam sesuai dengan posisi dada (Astriani et al., 2020). Hasil penelitian ini sejalan dengan Muliasari \& Indrawati (2018) super bubbles adalah teknik non farmakologi yang dapat dianalogikan dengan aktivitas permainan meniup objek yang terbuat dari bahan sabun cair yang aman digunakan anak bila nantinya ditiup secara perlahan dan dapat menghasilkan butiran-butiran gelembung. Peneliti menggunakan terapi bermain super bubbles karena, terapi bermain super bubbles selain memberikan efek distraksi juga memberikan relaksasi saat anak meniup gelembung secara perlahan.

Hasil penelitian ini sejalan dengan Ayuningtika et al., (2019) yang menyatakan bahwa terdapat hubungan terapi deep breathing meniup balon dengan skala nyeri anak yang dilakukan pengambilan darah di RSU Dr. Wahidin Sudiro Husodo Mojokerto karena semakin fokus responden terhadap deep breathing meniup balon maka akan semakin rileks tubuh dan impuls nyeri ke otak terhambat sehingga menurunkan skala nyerinya. Petugas kesehatan dapat menjadikan deep breathing meniup balon sebagai salah satu alternatif tindakan keperawatan mandiri selain juga pemberian obat analgesic dengan hasil penelitian menunjukkan $p$ value $0,000<\alpha(0,05)$.

Berdasarkan tabel 4 hasil penelitian dengan melakukan uji statistik $t$-dependent menunjukkan bahwa ada pengaruh meniup baling-baling bambu terhadap frekuensi pernafasan pada anak pada penderita pneumonia.

Menurut Ihsaniah (2019) bahwa bermain meniup dapat di analogikan dengan latihan nafas dalam (slow deep breathing) yang merupakan suatu permainan atau aktifitas yang memerlukan inhalasi lambat dan dalam untuk mendapatkan efek terbaik pada sistem pernapasan khususnya pneumonia dengan tujuan agar fungsi paru pada anak akan meningkat dan menjadi normal.

Hasil penelitian ini sejalan dengan penelitian Setyowati et al., (2017) yang menunjukkan bahwa setelah diberikan terapi meniup baling-baling didapatkan 13 responden $(38,2 \%)$ tidak mengalami nyeri dengan skala 0,14 responden $(41,2 \%)$ mengalami nyeri ringan dengan skala 1-3, 6 responden $(17,6 \%)$ mengalami nyeri sedang 
dengan skala 4-6, dan 1 responden (2,9\%) mengalami nyeri berat dengan skala 7-9. Hasil uji $t$-independent diperoleh nilai $p$ value 0,000 , sehingga dapat disimpulkan bahwa ada pengaruh pemberian terapi meniup baling-baling dalam menurunkan nyeri pada anak usia pra sekolah yang dilakukan fungsi vena di RSUD Tugurejo Semarang. Rekomendasi dari penelitian ini bahwa terapi meniup baling-baling sebagai tindakan mandiri farmakologis untuk menurunkan tingkat nyeri pada anak.

Hal tersebut didukung oleh penelitian yang dilakukan oleh Machsun et al., (2018) yang menyebutkan bahwa dari 19 responden yang diberikan interensi meniup balingbaling bamboo mengalami penurunan skala nyeri dengan nilai $p$ value 0,000, dan frekuensi nafas anak usia prasekolah teratur.

Hasil penelitian ini sejalan dengan Irfan et al., (2019) yang menunjukkan setelah intervensi napas buteyko dan blowing balloons dilakukan 2 kali sehari selama dua minggu didapatkan hasil uji wilcoxon sign rank test latihan napas buteyko dan latihan blowing balloons dengan nilai $p$ value 0,000 . Hasil uji mann withney menunjukkan tidak terdapat perbedaan mean rank skor asthma control test pada latihan napas buteyko dan latihan blowing balloons.

Penelitian yang dilakukan oleh Wahidati et al., (2019) suatu penelitian quasi eksperimental dengan jumlah sampel 34 responden didapatkan hasil pursed lips breathing lebih efektif dengan rata-rata 1,23 dibandingkan dengan tripod position 0,29. Latiahan nafas dapat membantu meningkatkan masuknya oksigen ke alveoli sehingga meningkatkan saturasi oksigen.

Saturasi oksigen pasien PPOK dapat ditingkatkan dengan terapi nonfarmakologi yaitu relaksasi pernafasan yaitu nafas dalam diindikasikan pada pasien PPOK dan dispnea. Latihan relaksasi pernafasan dapat meningkatkan inflasi alveolar maksimal, meningkatkan relaksasi otot, meningkatkan ventilasi alveoli, memelihara pertukaran gas, menghilangkan ansietas, dan mengurangi kerja pernafasan. Latihan pernafasan dapat dilakukan dalam beberapa posisi karena distribusi udara dan sirkulasi pulmonal beragam sesuai dengan posisi dada. Hal ini sejalan dengan hasil penelitian Mertha et al., (2018) menunjukkan bahwa nilai saturasi oksigen sebelum dilakukan intervensi ratarata sebesar $89,80 \%$ dan setelah dilakukan intervensi rata-rata sebesar $92.20 \%$ dengan selisih rat-rata sebesar $0,5 \%$. Hal ini menunjukkan bahwa intervensi deep breathing exercise dapat meningkatkan saturasi oksigen pada pasien PPOK.

Hal ini sejalan dengan hasil penelitian Royani (2017) hasil penelitian ini menunjukkan bahwa terapi aktivitas meniup balon dilakukan selama 1 bulan, dimana perlakuan dilakukan seminggu 3 kali. Setelah dilakukan intervensi meniup balon didapatkan frekuensi yang fungsi parunya baik sebanyak $18(60 \%)$ dan fungsi parunya kurang baik sebanyak 12 responden (40\%).

Penelitian yang dilakukan Astriani et al., (2020) Hasil pengukuran saturasi oksigen pada pasien PPOK setelah diberikan intervensi menunjukan saturasi oksigen meningkat sehingga terdapat pengaruh relaksasi pernafasan dengan teknik ballon blowing terhadap saturasi oksigen pada pasien PPOK di RSUD Kabupaten Buleleng. Ballon blowing sangat efektif untuk membantu ekspansi paru sehingga mampu mensuplai oksigen dan mengeluarkan karbondioksida yang terjebak dalam paru pada pasien dengan gangguan fungsi pernapasan.

\section{SIMPULAN}

Intervensi terapi tiup super bubbles dan meniup baling baling berpengaruh terhadap frekuensi pernafasan anak penderita pneumonia. 


\section{SARAN}

Berdasarkan penelitian dan pembahasan mengenai tiup super bubbles dengan meniup baling-baling bamboo terhadap frekuensi pernafasan anak penderita pneumonia. Saran bagi peneliti lain diharapkan dapat dijadikan acuan untuk mengkombinasikan dua intervensi ini pada klien dengan pneumonia. Selain itu juga penelitian selanjutnya dapat mengkolaborasikan kedua terapi ini dengan terapi lainnya.

\section{DAFTARPUSTAKA}

Apriliza, C., \& Zulaikha, F. (2018). Analisis Praktik Keperawatan pada An. A Post OP Thorakotomi Pemasangan WSD dengan Diagnosis Efusi Pleura dengan Intervensi Inovasi Terapi Slow Deep Breathing dengan Meniup Baling-Baling terhadap Penurunan Skala Nyeri dengan Tindakan Prosedur Invasif di Ruang PICU RSUD Abdul Wahab Sjahranie. Universitas Muhammadiyah Kalimantan Timur. https://dspace.umkt.ac.id//handle/463.2017/558

Astriani, Y., Dewi, S., \& Yanti, H. (2020). Relaksasi Pernafasan dengan Teknik Ballon Blowing terhadap Peningkatan Saturasi Oksigen pada Pasien Ppok. Jurnal Keperawatan Silampari, 3(2), 426-435. https://doi.org/doi: https://doi.org/10.31539/jks.v3i2.1049\%0

Ayuningtika, Y., Peni, T., \& Laili, S. I. (2019). Pengaruh Terapi Deep Breathing Meniup Balon Terhadap Skala Nyeri Anak yang Dilakukan Pengambilan Darah Di RSU Dr. Wahidin Sudiro Husodo Mojokerto. Sekolah Tinggi Ilmu Kesehatan Bina Sehat PPNI

Ihsaniah, H. I. (2019). Pengaruh Relaksasi Nafas Dalam Meniup Balon terhadap Intensitas Nyeri Anak Usia Prasekolah Pasca Bedah Di RSUD Dr. H. Abdul Moeloek Provinsi Lampung Tahun 2019. Politeknik Kesehatan Tanjungkarang

Irfan, M. Z., Suza, D. E., \& Sitepu, N. F. (2019). Perbandingan Latihan Napas Buteyko dan Latihan Blowing Ballons terhadap Perubahan Arus Puncak Ekspirasi pada Pasien Asma. Jurnal Perawat Indonesia, 3(2), 93. https://doi.org/10.32584/jpi.v3i2.314

Kemenkes, RI. (2017). Profil Kesehatan Indonesia 2016 dan Informasi Kesehatan

Machsun, T., Alfiyanti, D., \& Mariyam, M. (2018). Efektifitas Tehnik Relaksasi Napas Dalam dengan Meniup Baling-Baling terhadap Penurunan Skala Nyeri Pungsi Vena Pada Anak Usia Prasekolah. Jurnal Ilmu Keperawatan Anak, 1(1), 29. https://doi.org/10.32584/jika.v1i1.102

Mertha, I. M., Putri, P. J. Y., \& Suardana, I. K. (2018). Pengaruh Pemberian Deep Breathing Exercise terhadap Saturasi Oksigen pada PPOK di IGD RSUD Sanjiwani Gianyar Tahun 2018. Jurnal Gema Keperawatan, 11(1), 1-9. https://ejournal.poltekkes-denpasar.ac.id/index.php/JGK/article/view/253

Muliasari, Y., \& Indrawati, I. (2018). Efektifitas Pemberian Terapi Pursed Lips Breathing Terhadap Status Oksigenasi Anak Dengan Pneumonia. Ners Jurnal Keperawatan, 14(2), 92-101. DOI: 10.25077/njk.13.2.86-95.2017

Padila, P., Febriawati, H., Andri, J., \& Dori, R. A. (2019). Perawatan Infeksi Saluran Pernafasan Akut (Ispa) pada Balita. Jurnal Kesmas Asclepius, 1(1), 25-34. https://doi.org/10.31539/jka.v1i1.526

Riskesdas. (2018). Hasil Utama Riset Kesehatan Dasar. Kementrian Kesehatan Republik Indonesia, 1-100. https://doi.org/1 Desember 2013 
Royani, E. (2017). Pengaruh Terapi Aktivitas Bermain Meniup Balon terhadap Perubahan Fungsi Paru pada Anak dengan Asma di Rumah Sakit Islam Siti $\begin{array}{llll}\text { Khodijah Palembang. } & \text { Masker }\end{array}$ https://ejournal.stikesmp.ac.id/index.php/maskermedika/article/view/139

Setyowati, S. Y., Alfiyanti, D., \& Sumanto, D. (2017). Pengaruh Terapi Meniup BalingBaling terhadap Tingkat Nyeri Anak Usia Prasekolah yang Dilakukan Pungsi Vena di Rsud Tugurejo Semarang. Karya Ilmiah Stikes Telogorejo, 6(1), 1-8. http://ejournal.stikestelogorejo.ac.id/index.php/ilmukeperawatan/article/view/659

Suwastika, P. C. (2017). Perbedaan Tingkat Kecemasan Anak Prasekolah yang Mengalami Hospitalisasi Sebelum dan Sesudah Meniup Baling-Baling di Rs Myria Palembang. Universitas Katolik Musi Caritas

Wahidati, Hi., Dwiningsih, S. U., \& Putrono, P. (2019). The Effectiveness of Tripod Position And Pursed Lips Breathing to Enhance Oxygen Saturation in Patients With COPD. Jendela Nursing Journal, 3(2), 68-76. DOI: 10.31983/jnj.v3i2.4613

Widiyatmoko, A., \& Nur, D. W. (2018). Pengaruh Terapi Bermain Super Bubbles terhadap Kecemasan akibat Hospitalisasi pada Anak Pra Sekolah di Rsud Surakarta. Universitas Muhammadiyah Surakarta 